\title{
Seroprevalence of Peste Des Petits Ruminant's Virus Antibody in Assosa Zone, Benishangulgumuz Region, Ethiopia
}

\author{
ShimelsTikuye Yalew ${ }^{1 *}$, Gebrehiwot Woldemichal ${ }^{2}$, MulugetaZerihun Mamo \\ ${ }^{I}$ EIAR, National Agricultural Biotechnology Research Center, Holleta, Ethiopia \\ ${ }^{2}$ Regional Veterinary Diagnostic Laboratory, Assosa, Ethiopia
}

*Corresponding Author: ShimelsTikuye Yalew, National Agricultural Biotechnology Research Center, Holleta, Ethiopia. Email: shimelstk@gmail.com

\begin{abstract}
A cross-sectional study design was conducted to determine the seroprevalence and associated risk factors of Peste des Petits Ruminants Virus (PPRV) in four districts of Assosa zone, BenishangulGumuz region, Ethiopia from July to December 2017. A total of 321 serum samples were collected from sheep and goats. ID Screen ${ }^{\circledR}$ PPR competition kit was used for detection of PPRV antibodies by competitive ELISA in the sera of animals. The overall seroprevalence rate was found to be $75.7 \%$ (243/321) and species level prevalence rate was found $83.33 \%(n=15)$ in sheep and $75.25 \%(n=228)$ in goats. Among the small ruminants the seroprevalence of PPRV showed statistically significant variations $(P=0.0391)$, being very high in adult and low in young small ruminants. On the contrary there was no significance difference $(P>0.05)$ within districts, species, sex and body conditions. In conclusion PPRV was found to be important small ruminant disease in the study area, thus to control the disease and reduce the economic loss in this area, appropriate control strategies should be given.
\end{abstract}

Keywords: Assosa zone, ELISA, PPRV, Seroprevalence, small ruminant

Abbreviations: (c-ELISA) competitive enzyme linked immunosorbent assay, (ELISA) Enzyme linked immunosorbent assay, (L) Large protein, (Ml) Mille liter, (N) Nucleoprotein, (P) Phosphoprotein, (PPR) Peste des petitis Ruminants, (PPRV) Peste des petitis Ruminants virus

\section{INTRODUCTION}

Peste des petits ruminants (PPR) is an infectious and highly contagious disease that affects mainly small ruminants (sheep and goats) and wild ruminants (gazelles and antelopes) $[1,2,3]$.The PPR virus (PPRV) belongs to the genus Morbillivirus in the family Paramyxoviridae. It is closely related to the rinderpest virus of bovines and buffaloes, distemper virus of dogs and other wild carnivores, human measles virus and Morbilli viruses of marine mammals $[4,5]$. The disease is characterized by sudden depression, fever, mucopurulent ocular and nasal discharges, necrotizing and erosivestomatitis, severe enteritis, and pneumonia leading to death [6]. In epidemic areas, the morbidity rate is estimated from $80 \%$ to $90 \%$ and mortality rate ranges from $50 \%$ to $80 \%$ [7].

The genome of PPRV is single stranded RNA and having approximately $16 \mathrm{~kb}$ long with negative polarity [8]. PPR virion is enveloped, pleomorphic and composed of 15, 948 nucleotides, the longest of all morbillivirus genomes sequenced so far. This genomic RNA is wrapped by the nucleoprotein $(\mathrm{N})$ to form the nucleocapsid into which are associated two other viral proteins: the phosphoprotein $(\mathrm{P})$ and the large protein (L) [9]. PPR virus can be categorized into four distinct lineages (I, II, III and IV) based on fusion (F) and nucleoprotein $(\mathrm{N})$ gene sequencing. Among the four known lineages of PPR virus, lineage I and II viruses have been found exclusively in West Africa. Lineage III has been found in east Africa, identified in the outbreak of 1996 in Ethiopia, also in the Arabian Peninsula and southern India [10]. In Ethiopia, Clinical PPR was suspected in 1977 in afar region, eastern part of the country [11]. Clinical and serological evidence of its presence confirmed in 1991 in Addis Ababa [12]. PPR is continuously affecting small ruminants and contributing to food insecurity particularly in vulnerable regions of the country.

However accurate data on seroprevalence and information on associated risk factors of PPR infection is scarce in remote areas of the 
country. It is helpful to assess the seroprevalence of the disease to recommend possible prevention and control strategies which enhance poverty alleviation program in the country. ID Screen ${ }^{\circledR}$ PPR competition kit was used for detection of PPRV antibody from serum samples. Therefore the objective of the present study was aimed to determine the seroprevalence and identify potential risk factors of Peste des petits ruminant's virus (PPRV) in sheep and goats.

\section{MATERIALS AND METHODS}

\subsection{Study Area}

The study was conducted from July 2017 to December 2017 in Assosa, Bambasi, Homosha and Sherkole districts of Assosa zone from BenishangulGumuz regional state. In the study areas Small ruminants were reared under extensive management system and specific districts were randomly selected based on population density.

Asosa district is one of district of Asosa Zone situated in BenishangulGumuz Regional State. It is found between $34^{\circ} 12^{\prime} 32^{\prime \prime} \mathrm{N}$ and $10^{\circ} 35^{\prime} 45^{\prime \prime} \mathrm{E}$ and bordered with Bambasi district in the southern, Oda-buldigilu district in the eastern, Homosha district in the northern, Menge district north eastern, Kurmuk district in the north western, and republic of Sudan in the Western. It is $659 \mathrm{~km}$ far from capital city of Ethiopia. The elevation of the district ranges from5001500 meter above sea level and geographically, it is large made up of plain.

Bambasidistrict is located in BenishangulGumz Regional State of Ethiopia at $614 \mathrm{~km}$ far from the capital city, Addis Ababa and it is found between latitude $9^{0}-10^{0} 035 \mathrm{~N}$ and longitude $034^{0}-035^{0}$ E. Homosha district is one of the 20 districts in the BenishangulGumuz region of Ethiopia. Part of the Assosa zone, it is bordered by the Assosa on the south, Kurmuk on the northwest andMenge district on the east. Sherkoleis found in Assosa zone of Benishangul Gumuz region, bordered with Menge on the south, Kurmuk district on the west, with Sudan on the north and Kamashi zone on the east.

\subsection{Study Animals}

A total of 321 small ruminants (sheep and goat) managed extensively were randomly selected and subjected to serological analysis by competitive enzyme linked immunosorbent assay (c-ELISA) kit to determine the seroprevalence of PPRV in the study area. The selected animals were from different districts, species, and age, sex and body condition groups.

\subsection{Study Design and Sampling Technique}

A cross-sectional study design was conducted in districts of Assosa zone, BenishangulGumuz regional state of Ethiopia from July 2017 to December 2017. The study districts were selected purposely based on their small ruminant population and accessibility. A simple random sampling technique was applied for selection of animals. Finally, animals were selected to test the occurrence of the virus antibody in the selected areas. Districts, species, sex, age and body conditions were concerned as hypothesized risk factors. All sampled sheep and goats were local breed and reared under extensive management system. All necessary information was collected on individual animal bases using a structured questionnaire format.

\subsection{Sample Collection}

Blood samples (4ml) were collected from Jugular vein using sterile needles and plain vacationer tube labeled with identification number, species, sex, age, body condition and etc. The samples were putted in tilted position at room temperature until the clot was fully separated from the serum. Sera were decanted into cryo-vials, identified and stored at $-20^{\circ} \mathrm{C}$ until screened for antibodies against natural PPR virus infection using serological analysis.

\subsection{Laboratory Diagnosis}

Serum samples were analyzed by using aID Screen ${ }^{\circledR}$ PPR competition kit according to the instructions of the manufacturer (France) in Assosa Regional Veterinary Diagnostic Laboratory (Assosa, Ethiopia).

\subsection{Data Management and Analysis}

Data generated from field and laboratory investigations were recorded and coded by using Microsoft Excel spreadsheet and descriptive statistics were applied to calculate the proportion.

The association of potential risk factors such as districts, species, sex, age and body condition with PPRV were assessed using R-Software.

\section{RESULTS AND DISCUSSION}

ID Screen ${ }^{\circledR}$ PPR competition kit was used to determine seroprevalencerate of PPRV antibody showed that from a total of 321 small ruminants examined for the presence of PPRV antibody, 
243small ruminants revealed PPRV antibody in their serum sample with the overall prevalence rate of $75.7 \%$. The odds ratio value of the intercept was $1.583093 \mathrm{e}-08$ which indicates the odds of prevalence of PPR when risk factors held constant. The prevalence rate was higher in Assosadistrict $(85.12 \%)$ and lower in Bambasi (75\%), Sherkole (69.9\%) and Homosha

Table1: prevalence of PPRV antibody in small ruminants and its association with various risk factors in selected districts of Assosa zone

\begin{tabular}{|c|c|c|c|c|c|c|}
\hline & \begin{tabular}{|l} 
No examined \\
\end{tabular} & No of positives & Prevalence \% & Coefficients & Odds ratio & P-value \\
\hline Risk factors & & & & -17.9613 & $1.583093 \mathrm{e}-08$ & \\
\hline \multicolumn{7}{|c|}{ Districts } \\
\hline Bambasi & 20 & 15 & $75 \%$ & -1.1116 & $3.290287 \mathrm{e}-01$ & 0.2993 \\
\hline Homosha & 55 & 38 & $69.09 \%$ & -0.1689 & $8.446044 \mathrm{e}-01$ & 0.8515 \\
\hline Sherkole & 125 & 87 & $69.6 \%$ & -0.7684 & $4.637731 \mathrm{e}-01$ & 0.2798 \\
\hline Assosa & 121 & 103 & $85.12 \%$ & \multicolumn{3}{|c|}{ Reference } \\
\hline \multicolumn{7}{|c|}{ species } \\
\hline Sheep & 18 & 15 & $83.33 \%$ & -1.2216 & $2.947700 \mathrm{e}-01$ & 0.2877 \\
\hline Goat & 303 & 228 & $75.25 \%$ & \multicolumn{3}{|c|}{ Reference } \\
\hline \multicolumn{7}{|c|}{ sex } \\
\hline Male & 52 & 41 & $78.85 \%$ & 0.3642 & $1.439356 \mathrm{e}+00$ & 0.6994 \\
\hline Female & 269 & 202 & $75.09 \%$ & \multicolumn{3}{|c|}{ Reference } \\
\hline \multicolumn{7}{|c|}{ age } \\
\hline Young & 47 & 28 & $59.57 \%$ & -1.4264 & $2.401823 \mathrm{e}-01$ & 0.0391 \\
\hline Adult & 274 & 215 & $78.47 \%$ & \multicolumn{3}{|c|}{ Reference } \\
\hline \multicolumn{7}{|c|}{ Body Condition } \\
\hline Medium & 49 & 4 & $8.16 \%$ & 16.1028 & $9.847991 \mathrm{e}+06$ & 0.9903 \\
\hline Poor & 249 & 239 & $95.98 \%$ & 22.0680 & $3.837157 \mathrm{e}+09$ & 0.9867 \\
\hline Good & 23 & 0 & $0 \%$ & \multicolumn{3}{|c|}{ Reference } \\
\hline
\end{tabular}

Prevalence of PPRV antibody in sheep and goatswere $83.33 \%$ and $75.25 \%$ respectively. However, there was no significant difference $(\mathrm{P}$ $>0.05$ ) observed between species of the study animals. When the species was sheep the prevalence rate of PPRV is decreases by 1.2216 $\log$ odds than goat which was the reference (Table 1).

Prevalence rate of PPRV antibody in male and female small ruminants was $78.85 \%$ and $75.09 \%$ respectively. But the difference was not statistically significant $(p>0.05)$ with in sex of the study animals. When the sex was male the prevalence rate of PPRV increases by $0.3642 \mathrm{log}$ odds than female which were the reference.

Prevalence rate of PPRV antibody was high in adult $(78.47 \%)$ and low in young (59.57\%) small ruminants. Young age category has a coefficient $=-1.4264$ and $p$-value $=0.0391$ meaning the prevalence of PPR is significantly associated with age hence the p-value is less than 0.05 and here the reference is adult age category which indicates that when the age group is young the prevalence rate of PPRV decreases by $1.4264 \log$ odds (Table 1).
$(69.09 \%)$ districts respectively. Infection rate was statistically nonsignificant $(\mathrm{P}>0.05)$ between the study sites. When the district was Bambasi, Homosha and Sherkolethe prevalence of PPRV decreases by 1.1116, 0.1689 and $0.7684 \log$ odds respectively here the reference district is Assosadistrict (Table 1). 
Bambasi (75\%), Sherkole (69.9\%) and Homosha $(69.09 \%)$ districts respectively. The infection rate was statistically no significant $(\mathrm{P}>0.05)$ between the study sites but the differences might be due to variations in agro climatic conditions and sample size.

The status of PPRV antibody in sheep and goats were $83.33 \%$ and $75.25 \%$ respectively. However, there was no significant difference (P $>0.05)$ recorded. The situation is also observed in studies conducted in Republic of Chad [19] and On the contrary, other studies have revealed the reverse as in Siltie and Gurage zones, Ethiopia, [14]. The difference might be due to the internal factors of the species and probably to the sensitivity of certain animals to the lineages of the virus.

The seroprevalencerate of PPRV antibody between male and female small ruminants was $78.85 \%$ and $75.09 \%$ respectively but the difference was not statistically significant (p>0.05). Similar result was found by [20] who recorded no statistical significance in prevalence between males and females in Nigeria. This might be due to equal exposure of both male and female small ruminants to the virus because they are herded together and shared communal grazing.

Prevalence rate of PPRV antibody was recorded high in adult (78.47\%) and low in young (59.57\%) small ruminants. The prevalence of PPRV is significantly associated with age hence the p-value is less than 0.05 and here the reference is adult age category which indicates that when the age group is young the prevalence rate of PPRV decreases by $1.4264 \mathrm{log}$ odds. The present findings are in agreement with previous reports by[21] and[22] who found that adult small animals were more sero-positive to PPRV antibody. Age appears to be a factor for seropositive status and its linear relation suggests that PPRV is highly immunogenic, naturally infected animals remaining positive for a long time [23]. It is because greater probability of older animals to be exposed to PPRV but young, having been in the herds for a shorter period, is less likely to have been in contact with virus.

Prevalence rate of PPRV antibody was higher in a poor body condition $(95.98 \%)$ than animals with having medium (8.16\%) and good body condition $(0 \%)$ respectively. But there was no Significant difference $(\mathrm{P}>0.05)$ recorded among body conditions of the study animals. This signifies that the importance of PPRV in causing weight loss. Furthermore, PPRV also led to a loss of appetite and poor utilization of food, which results in a loss of body weight.

\section{CONClusion}

Our study shows that PPR virus has extensively circulated across the study districts. The presence of such a devastating virus poses a serious hindrance to small ruminant productivity. It is currently a major socioeconomic animal health problem in the area. Our study provides preliminary information on PPRVsero-prevalence and possible associated risk factors. Therefore, we recommend a more active serological and virological surveillance programs in the study area in addition to implementing intensive vaccination campaigns.

\section{REFERENCES}

[1] Chauhan, H. C., Chandel, B. S., Kher, H. N., Dadawala, A. I., \& Agrawal, S. M., Pesti des petits ruminants virus infection in animals. Veterinary World, 2(4), (2009).

[2] Bao, J., Wang, Z., Li, L., Wu, X., Sang, P., Wu, G., Wang, J., Detection and genetic characterization of peste des petits ruminants virus in free-living bharals (Pseudois nayaur) in Tibet, China. Research in Veterinary Science, 90(2), 2011, 238-240.

[3] Lembo, T., Oura, C., Parida, S., Hoare, R., Frost, L., Fyumagwa, R., Cleaveland, S., Peste des petits ruminants infection among cattle and wildlife in northern Tanzania. Emerging Infectious Diseases, 19(12), 2013, 2037.

[4] Giavedoni, L., Jones, L., Mebus, C., \& Yilma, T., A vaccinia virus double recombinant expressing the $\mathrm{F}$ and $\mathrm{H}$ genes of rinderpest virus protects cattle against rinderpest and causes no pock lesions. Proceedings of the National Academy of Sciences, 88(18), 1991, 8011-8015.

[5] Waret-Szkuta, A., Roger, F., Chavernac, D., Yigezu, L., Libeau, G., Pfeiffer, D. U., \& Guitián, J., Peste des Petits Ruminants (PPR) in Ethiopia: Analysis of a national serological survey. BMC Veterinary Research, 4(1), 2008, 34.

[6] Munir, Muhammad, Zohari, S., \& Berg, M., Pathophysiology and clinical assessment of peste des petits ruminants. In Molecular biology and pathogenesis of Peste des Petits Ruminants virus,2013,(pp. 33-48). Springer.

[7] Debnath, N. C., peste des petits ruminants (PPR). An Overview, Proceeding of the BSVER Symposium on Eradication of Rinderpest and Related Disease, 2, 1995, 9-13.

[8] Haas, L., Baron, M. D., Liess, B., \& Barrett, T., Editing of morbillivirus $\mathrm{P}$ gene transcripts in 
infected animals. Veterinary Microbiology, 44(2-4), 1995, 299-306.

[9] Diallo, A., Minet, C., Le Goff, C., Berhe, G., Albina, E., Libeau, G., \& Barrett, T., The threat of peste des petits ruminants: progress in vaccine development for disease control. Vaccine, 25(30), 2007, 5591-5597.

[10] Dhar, P., Sreenivasa, B. P., Barrett, T., Corteyn, M., Singh, R. P., \& Bandyopadhyay, S. K., Recent epidemiology of peste des petits ruminants virus (PPRV). Veterinary Microbiology, 88(2), 2002, 153-159.

[11] Pegram, R. G., \& Tereke, F., Observation on the health of Afar livestock. Ethiopian Vet J, 5, 1981, 11-14.

[12] Abraham, P. L., Kenfe, G., \& Barrett, T., PPR in Ethiopian goats. Trop Anim Health Prod, 26, 1994, 69-73.

[13] Gari, G., Serda, B., Negesa, D., Lemma, F., \& Asgedom, H., Serological Investigation of Peste Des Petits Ruminants in East Shewa and Arsi Zones, Oromia Region, Ethiopia. Veterinary Medicine International, 2017.

[14] Hailegebreal, G.,Journal of Veterinary Science \& Technology, 2018

[15] Farougou, S., Gagara, M., \& Mensah, G. A., Prevalence of peste des petits ruminants in the arid zone in the Republic of Niger. Onderstepoort Journal of Veterinary Research, 80(1), 2013, 1-6.

[16] Munir, M, Saeed, A., Abubakar, M., Kanwal, S., \& Berg, M., Molecular Characterization of Peste des Petits Ruminants Viruses From Outbreaks Caused by Unrestricted Movements of Small Ruminants in $\mathrm{P}$ akistan. Transboundary and Emerging Diseases, 62(1), 2015, 108-114.

[17] Bwihangane, B. A., Misinzo, G., Sviteck, N., Bebora, L. C., \& George, C. G., Seroepidemiology of peste des petits ruminants infection and the associated risk factors in
South Kivu, DR. Congo. Fifth African Higher Education Week and RUFORUM Biennial Conference 2016," Linking Agricultural Universities with Civil Society, the Private Sector, Governments and Other Stakeholders in Support of Agricultural Development in Africa", Cape Town, South Afr, 2016,737-746.

[18] Ibrahim, H. M. Z. A.,Sero-prevalence of Pestedes Petits Ruminants Virus (PPRV) Antibodies in Sheep and Goats from North and Central Sudan. Sudan University of Science \& Technology, 2018

[19] Mahamat, O., Doungous, T., Kebkiba, B., Oumar, H. A., Oussiguéré, A., Yacoub, A. H., ... Moussa, A. H., Seroprevalence, geographical distribution, and risk factors of peste des petits ruminants in the Republic of Chad. Journal of Advanced Veterinary and Animal Research, 5(4), 2018, 420-425.

[20] Woma, T. Y., Ekong, P. S., Bwala, D. G., Ibu, J. O., Ta'ama, L., Dyek, D. Y., ... Bailey, D., Serosurvey of peste des petits ruminants virus in small ruminants from different agroecological zones of Nigeria. Onderstepoort Journal of Veterinary Research, 83(1), 2016, 1-9.

[21] El-Yuguda, A.-D., Saheed Baba, S., Ganiyu Ambali, A., \& Egwu, G. O., Seroprevalence of peste des petits ruminants among domestic small and large ruminants in the semi-arid region of North-eastern Nigeria. Veterinary World, 6(10), 2013.

[22] Acharya, N., Poudel, S. P., \& Acharya, K. P., Cross-sectional sero-prevalence study of Peste des Petits Ruminants (PPR) in goats of Syangja and Kaski districts of Nepal. VirusDisease, 29(2), 2018, 173-179.

[23] Roger, F., Chavernac, D., Yigezu, L., Libeau, G., Pfeiffer, D. U., \& Guitian, J., Peste des Petits Ruminants (PPR) in Ethiopia: Analysis of a national serological survey. BMC Veterinary Research (4), Inconnu. (2008).

Citation: ShimelsTikuye Yalew, Gebrehiwot Woldemichal, MulugetaZerihun Mamo, Seroprevalence of Peste Des Petits Ruminant's Virus Antibody in Assosa Zone, Benishangulgumuz Region, Ethiopia, ARC Journal of Animal and Veterinary Sciences. 2019; 5(3):29-33. doi: dx.doi.org/10.20431/2455-2518.0503004.

Copyright: (c) 2019 Authors. This is an open-access article distributed under the terms of the Creative Commons Attribution License, which permits unrestricted use, distribution, and reproduction in any medium, provided the original author and source are credited. 